\title{
Mitochondrial Hydroxyacyl-Coenzyme A Dehydrogenase Hyperinsulinism
}

National Cancer Institute

\section{Source}

National Cancer Institute. Mitochondrial Hydroxyacyl-Coenzyme A Dehydrogenase

Hyperinsulinism. NCI Thesaurus. Code C131837.

Hyperinsulinism due to inactivating mutation(s) in the gene $\mathrm{HADH}$, encoding mitochondrial (short-chain) hydroxyacyl-coenzyme A dehydrogenase, resulting in loss of inhibition of g lutamate dehydrogenase (GDH). This condition is also characterized by protein-induced hypoglycemia, but in contrast to GLUD1-associated hyperinsulinism, hyperammonemia is absent. 